\title{
УДК 658.589:303.43
}

Рибак Сергій Олександрович, кандидат економічних наук, старший науковий співробітник, доцент, провідний науковий співробітник Інституту світової економіки і міжнародних відносин НАН України

Лисецька Нелі Миколаївна, молодший науковий співробітник Інституту світової економіки і міжнародних відносин НАН України

\section{МІЖНАРОДНЕ СПІВРОБІТНИЦТВО ЯК ЗАПОРУКА ІННОВАЦІЙНОГО ПРОЦЕСУ В НАЦІОНАЛЬНІЙ ЕКОНОМІЦІ}

\begin{abstract}
Анотація
В роботі доведено необхідність світової кооперації в напрямку подальшої інтенсифікації інноваційних процесів і зокрема оцінена сучасна позиція України в системі, зокрема, Європейської програми інноваційного обміну між країнами. Проаналізовані сучасні програми Європейської кооперації в інноваційній співпраці країн. Визначені основні галузі інноваційного потенціалу України.

Ключові слова: інноваційний розвиток, міжнародне співробітництво, фінансові механізми.

\section{Вступ}

Рівень інноваційного розвитку держави тісно пов'язаний з загальним станом iï економічної системи. Щоб інтегруватися в міжнародний економічний простір, економіка країни має досягти наближених показників розвитку розвинених ринкових систем, пройти стадію ефективного внутрішнього ринку, вичерпати відповідний ресурс розвитку і здійснити поступове входження до транснаціональних економічних структур. Така країна повинна мати високодиференційовану, сучасну структуру економіки, із значною часткою виробництв, які виступають основними суб'єктами міжнародних інтеграційних взаємовідносин на макроекономічному рівні.

На сучасному етапі Україна демонструє дисбаланс між розвитком зовнішнього та внутрішнього ринку. Причому такий стан $€$ наслідком не природногеографічної обмеженості ринкового простору, а недорозвиненості у його структурно-функціональної організації, недостатньої практичної розвиненості у суто економічному сенсі [1]. Таким чином, ускладнюється реалізація
\end{abstract}


найважливіших завдань: як технологічне оновлення традиційних галузей економіки і створення нових виробництв.

Метою статті $€$ дослідження внутрішніх та зовнішніх чинників інноваційного розвитку України.

\section{1. Чинники інноваційного розвитку України}

Розглянемо позитивні та негативні чинники що впливають на інноваційний розвиток України.

Як засвідчує досвід багатьох країн світу ситуація, яка на сьогодні існує в Україні, може уповільнити процес набуття економічними суб"єктами сутнісних характеристик носіїв відносин інтеграційного типу. Виправити ситуацію могло б ефективне міжнародне економічне співробітництво, яке б стимулювало залучення іноземного капіталу, розвиток інноваційної діяльності. Для цього потрібно стабілізувати політичну ситуацію та інвестиційннй клімат в державі, стимулювати розвиток економічної та соціальної сфери.

Перспективними напрямами на сучасному етапі розвитку України $\epsilon$ підтримка та розвиток найтісніших міжнародних зв'язків в науково-технічному та освітньому співробітництві з європейськими та азіатськими країнами, з США та СНД. Як вважає академік А.Шпак: «...інтеграція України в світовий науковий простір розширилась, зросла договірно-правова база міжнародного співробітництва. За останніх п’ять років підписано та поновлено понад 30 документів, що регламентують наукове співробітництво 3 низкою наукових організацій 40 країн. Станом на початок 2009 р. діє понад 100 угод з зарубіжними академіями i науковими центрами практично всіх провідних країн Європи, Америки, Азії. Практично 90\% організацій Академії наук України бере участь у різних формах міжнародної кооперації. Важливим кроком в процесі наукової кооперації стали поглиблення зв’язків та перехід до нових форм співпраці 3 Національним центром наукових досліджень Франції (CNRS), Радою з наукових досліджень Туреччини (TUBITAK), Російськими гуманітарними науковими фондами фундаментальних досліджень».

Одним 3 негативних чинників виступає особливість української зовнішньоторговельної політики України. Він полягає у спеціалізації країни у галузях, де переважає виробництво сировинної продукції та напівфабрикатів. 
Також, однією з основних диспропорцій, що сформувалася у ході ринкових реформ в Україні, є неприпустимо низька частка національного доходу (близько 40 \%), яка розподіляється на користь найманих працівників (у розвинених країнах - понад $70 \%)$.

Маємо зазначити, що в Україні склалася ситуація, коли на найвищому державному рівні проголошені певні зовнішньоекономічні та політичні пріоритети. Це потребує належної практичної реалізації - це орієнтація на входження до єдиного регіонального простору ЄС, яка відкриває перед Україною перспективи інтенсифікації процесів, вони мають забезпечити перехід суспільства від індустріальної до постіндустріальної моделі розвитку. Дослідження головної стратегічної мети зовнішньоекономічної політики України в євроінтеграційному контексті - отримання статусу асоційованого члена СС актуалізує необхідність всебічного розширення співробітництва України і Євросоюзу, у тому числі у інноваційному напрямку. Інтеграція до Європейського Союзу повинна стимулювати розвиток якісно нового, вищого рівня життя для усього суспільства, $\mathrm{i}$ це має бути забезпечено за рахунок новітніх технологій, ефективного і безпечного використання природних та трудових ресурсів країни шляхом активізації зусиль по реформуванню ринків капіталів, товарів і праці.

3 іншого боку принциповою проблемою для здійснення євроінтеграційних перспектив української держави лишається той факт, що доступ до європейських та світових ринків високотехнологічної продукції практично закрито для України. Навіть там, де Україна виготовляє досить висококонкурентоспроможний продукт, наприклад космічна та авіаційно-будівельна галузі, через політичні преференції та низький світовий імідж Україна не може вийти гідний міжнародний рівень. (Україна посідає 115 місце серед 125 країн по виконанню міжнародних договорів та зобов' язань).

За такої ситуації, особливо важливим напрямком участі України в європейському інтеграційному процесі $\epsilon$ створення інноваційно-орієнтованої суспільної системи, а також розвиток високих технологій та включення нашої країни в глобальний високотехнологічний обмін.

\section{2. Напрямки інноваційних інтеграційних процесів України}


Перспективним напрямком інноваційних інтеграційних процесів України в $€ \mathrm{C} \epsilon$ Угода про наукове і технічне співробітництво. Вона визначила конкретні напрями співробітництва в галузі фундаментальних наукових досліджень та технологічного розвитку, а саме: дослідження наукового середовища та клімату, включаючи спостереження земної поверхні; біометричні дослідження та дослідження в галузі охорони здоров'я; промислові та виробничі технології; ядерна енергетика; транспорт; технологія інформаційного суспільства; науково-технічна політика; навчання та обмін науковими кадрами.

Багатоаспектна мета такого співробітництва - це стабілізація дослідницького потенціалу України, розв'язання проблем, що становлять спільний інтерес, та прискорення інтеграції України в СС. Співпраця України з Свросоюзом у науковотехнологічному напрямку сприятиме інтенсифікації політичних та економічних відносин, застосування нових механізмів стимулювання перспективних досліджень, розвитку громадського усвідомлення щодо значення науки в розвитку суспільства.

Координація спільного дослідницького інтересу i координація у технологічній сфері є додатковим шляхом інтеграції України (через формування єдиного науково-технічного простору) до Євросоюзу. Особливе значення має факт обопільної вигоди від реалізації дослідницьких програм.

Позитивним рішенням стало посилення координаційного механізму. 3 цією метою створено спільний комітет Україна-Співтовариство зі співробітництва в галузі науки та технологій. Таким чином, ухвалено причинні детермінанти науково-технічної інтеракції між Україною та ЄС, а саме: взаємна вигода; своєчасний обмін інформацією; збалансоване отримання Україною та Співтовариством економічних і соціальних результатів від спільної діяльності в науковій сфері.

Глибші форми співпраці та взаємодії, які пропонує ЄС для своїх сусідів поширюються на спільні норми та стандарти, права інтелектуальної власності, правила конкуренції, захист споживача та механізми співпраці державних органів країн-сусідів.

Зокрема, в рамках співробітництва України та СС запроваджується новий механізм співпраці державних органів країн ЄС і України - твінінг. Твінінг - один 
iз нових підходів щодо наближення українського законодавства до норм, які прийняті в Європі, а також щодо впровадження в Україні сучасного досвіду керівництва державними органами. Цей механізм працює наступним чином. В країні вибирається державна структура. яка потребує допомоги 3 боку Європейського Союзу щодо впровадження європейських норм. Це відомства що мають проблемні питання та бажання удосконалити свою структуру. Зокрема, це Мінфін, який керує бюджетним процесом, Мінекономіки, Мінтранс. Заявки на таку допомогу надсилаються до всіх 27 країн СС. Деякі 3 них пропонують свою допомогу. На конкурсних засадах обирається такий проект, який найкраще відповідає потребам країни-отримувача. Тоді відповідна структура держави-донора надає допомогу щодо впровадження сучасних технологій управління, наближення місцевого законодавства до законів ЄС. [3,c.25]. Розширення дії інструменту твінінгу на України є значним кроком уперед, що демонструє зростаючий рівень інтеграції України у Свропростір.

У європейських країнах стимулювання інноваційної діяльності виходить за національні межі і дедалі більшою мірою стає прерогативою ЄС. Пріоритетні напрями інноваційної політики ЄС були відображені в 19 програмах, які охоплювали інформаційні технології та телекомунікації, програми виробничих технологій і матеріалів, навколишнього середовища i клімату, біомедицини й охорони здоров'я, сільського господарства і керованого термоядерного синтезу. Європейська комісія схвалила План дій у сфері інновацій, у якому на рівні 3 фінансуванням (шляхом мобілізації венчурного капіталу на ранніх стадіях проектів) намічено реалізувати і методи непрямої дії.

Останні Рамкові програми передбачають вкладення 162 млн. євро на дослідження малих і середніх підприємств, 70 млн. євро виділяються на організацію спеціальних досліджень спільно з партнерами із нових членів ЄС у таких областях, як eGovernment, eHealth, eLearning або eBusiness. Фінансові перспективи, запропоновані Сврокомісією на період 2007-2013 рр, забезпечують 80\%-ве зростання щорічних витрат на дослідження [4,с.15]. Також 50 млрд. евро витратить Європейський Союз на розвиток наукових досліджень у 2007-2013 роках. Пріоритетними сферами досліджень є: енергетика, медицина, біотехнології, нанотехнології, суспільні та гуманітарні науки, космічні, безпека та довкілля. 
Створення єдиного Європейського дослідницького простору передбачає залучення в нього не тільки старих, але і нових членів $\mathrm{CC}$, а також держав, що підписали угоду про науково-технічне співробітництво з Євросоюзом (у 2001 р. такі угоди було підписані з Росією, Україною, Мальтою та Індією). Стаття 169 Договору про створення СС передбачає спільне проведення національних програм країн-учасниць i асоційованих держав. Дана стаття $\epsilon$ найбільш дієвим інструментом для створення єдиного Європейського дослідницького простору, оскільки дозволяє країнам-кандидатам брати участь у Сьомій Рамковій програмі на тих же умовах, що i повноправним членам ЄС. Аналогічні права надані i міжнародним організаціям, які представляють європейські інтереси.

На сучасному етапі діє широкомасштабна Сьома Рамкова програма, яка спрямована на розвиток досліджень та інновацій. Бюджет цієї програми - понад 54 мільйонів євро. Попередні програми були заплановані на чотири роки, а Сьома Рамкова програма має діяти сім років. Вона буде допомагати малому бізнесу, використовувати свої можливості на користь всієї Європи та продовжувати розвиток попередніх напрямків: інвестування у дослідницьку інфраструктуру: розвиток транскордонних дослідницьких мереж у сфері медицини; соціологічні дослідження, біотехнології, харчова промисловість та сільське господарство, інформаційне суспільство, нанотехнології, матеріали та виробництво, енергетика, довкілля, транспорт, також безпека й космос, що охоплюють різні країни. Щоб досягти розвитку цих напрямів, одним із ключових пріоритетів повинен стати так званий «трикутник знань» - це вироблення, передача та використання знань через дослідження, освіту, професійне навчання та розвиток інновації [2].

Незважаючи на європейські успіхи в науці та освіті, практика вказує на очевидні ускладнення в адаптуванні цих досягнень на європейських підприємствах. Коли йдеться про створення й упровадження нових технологій, Свропа відстає від провідних країн у цій сфері. Відсутність чіткої програми інноваційного розвитку, яка дозволить розпочати випуск нової продукції й послуг, призводить до того, що бізнесові структури не мають бажання вкладати інвестиції у цю сферу в Європі. Світовий відсоток патентів, виграних компаніями СС в останні роки зменшився. Конкуренти з Північної Америки та Азії більш успішно втілюють інновації та співпрацюють із промисловими лідерами й науковими дослідниками інших країн. Талановиті вчені міжнародного рівня охоче проводять фундаментальні та 
прикладні дослідження в країнах Америки та Азії. Тому 8 червня 2006 р. Європейська комісія оприлюднила подробиці свого плану створення Європейського технологічного Інституту [5, с.17]. Цей Інститут міг би відігравати передову роль у передачі наукових знань, залучаючи до співпраці кращих дослідників і компанії з усього світу, посилюючи європейський потенціал у наукових дослідженнях і технологіях, стимулюючи кар'єрний ріст дослідників, заохочуючи європейських науковців залишатися в Свропі та залучати талановитих вчених з усього світу до Свропи.

В умовах недостатнього фінансування науки в Україні, особливу увагу привертає пропозиція щодо фінансування участі у цьому проекті дослідників третіх країн. Загальні щорічні витрати країн ЄС на двостороннє науково-технічне співробітництво 3 третіми країнами становлять 750 млрд. євро. Із затрачених коштів країни колишнього Радянського Союзу отримують приблизно 10 \%, або 75 млрд євро. Запроваджується такий новий інструмент інтеграції європейського дослідництва як створення Мережі майстерності; впровадження інтегрованих проектів, на що передбачено виділення 300 млн. євро. Додаткове фінансування дослідників з третіх країн в обсязі 300 млн. євро. ставить перед Україною завдання проаналізувати свої потреби щодо забезпечення участі українських вчених, наукових установ у інтегрованих проектах та Мережі досконалості, що може бути повністю профінансовано Програмою. Нагальною потребою для української сторони є опрацювання додаткових схем підтримки та використання спеціальних інструментів, таких як координація та поєднання можливостей дослідницьких програм з ресурсами програми TASIC. Угодою передбачено, що за умови надання ЄС учасникам української сторони грантів, фінансової чи іншої допомоги на таку допомогу розповсюджуються податкові та митні пільги як з боку ЄС так i української сторони, що потребує узгодження 3 податковим законодавством України (передбачено звільняти гранти від сплати мита, будь-яких митних зборів, податків на додану вартість, податків на прибуток, а також від сплати всіх інших податків і зборів).

Значне місце у міжнародній науковій співпраці України посідає США. Пріоритетними напрямами двосторонньої співпраці України та США у сфері науки і технологій $є$ такі: 
- фундаментальні дослідження з низки актуальних проблем природничих, соціальних та гуманітарних наук;

- новітні технології енергозбереження у галузі промисловості, охорона довкілля та питання сталого розвитку;

- новітні технології діагностики і лікування найбільш поширених i складних захворювань;

- мирне освоєння космосу;

- проблеми демографічного розвитку та становлення громадянського суспільства.

Одним 3 найбільш активних напрямів взаємодії на сьогодні $\epsilon$ співробітництво у сфері охорони здоров'я, передусім у контексті заходів 3 попередження та боротьби з такими небезпечними захворюваннями як ВІЛ/СНІД, туберкульоз та різні небезпечні види грипу. Співпраця у сфері боротьби 3 ВІЛ/СНІД здійснюється відповідно до Стратегії Агентства міжнародного розвитку США з протидії ВІЛ/СНІД в Україні на 2003-2009 р. В рамках зазначеної стратегії реалізується низка проектів, які фінансує США.

Наразі Уряд США в рамках двосторонньої Угоди про співробітництво у галузі запобігання розповсюдженню технологій, патогенів та знань, які можуть бути використані в ході розробки біологічної зброї надає допомогу на ці цілі Міністерству охорони здоров’я та Мінагрополітики України у вигляді обладнання, яке потребують відповідні організації і установи України.

Взагалі, співпраця з США здійснюється в основному через американські міжнародні фонди та через наукові та інші програми. Наприклад, програма SABIT була розроблена в 1990 р. Міжнародною Адміністрацією Торгівлі в Міністерстві Торгівлі США у Вашингтоні. Мета програми - сприяння економічній реструктуризації країн СНД - Вірменії, Азербайджану, Білорусі, Грузії, Казахстану, Молдови, Росії, Таджикистану, Туркменістану, України і Узбекистану. SABIT проводить стажування менеджерів середньої і вищої ланки, вчених і інженерів країн СНД в малих, середніх і великих американських компаніях і недержавних організаціях.

Під час стажування велику увагу надається спеціалізованій галузевій підготовці, вивченню концепцій західного менеджменту i принципів 
функціонування ринкової економіки, що необхідне для підтримки економічного розвитку і залучення зарубіжних інвестицій в країни СНД. SABIT також надає унікальну можливість як американським компаніям, що беруть участь в проведенні програми стажування, так і стажистам з СНД встановити і підтримувати та розвивати ділові відносини, які є заставою успішної діяльності на світовому ринку.

Міжнародне науково-технічне співробітництво з країнами СНД триває в рамках формування спільного науково-технологічного простору держав -учасниць СНД. Слід зазначити, що практично з усіма країнами СНД було укладено або погоджено міжурядові угоди та договори в галузі науки і технологій. Здається логічним подальший розвиток цих відносин, розвиток одного 3 провідних зовнішніх ринків збуту українських товарів та підвищення ефективності реалізації режиму вільної торгівлі.

Основним напрямом організації двостороннього науково-технічного співробітництва було формування, реалізація, коригування переліку пріоритетів та проектів Програм співробітництва в галузі науки i технологій як складової Програми довгострокового економічного співробітництва України 3 державами СНД.

\section{Висновки}

Резюмуючи вищесказане, маємо зазначити, що перспективними напрямами на сучасному етапі України є підтримка та розвиток найтісніших міжнародних зв’язків в науково-технічному та освітньому співробітництві з європейськими та азіатськими країнами, з США та СНД. Інтенсифікація міжнародної науковотехнологічної співпраці України є необхідною для досягнення стратегічних цілей осучаснення науково-технологічного базису держави, посилення іiі інтеграційного потенціалу в регіоні i світі, входження українського соціуму до постіндустріального інформаційного суспільства. Разом 3 тим слід зафіксувати невисоку практичну спроможність української сторони до інтеграції високорозвиненої системи науково-технологічних взаємозв'язків. Щоб зайняти вагомі позиції у міжнародній кооперації необхідно розвивати новітні технології, активізуючи міжнародне співробітництво у науково-технічній сфері. Пріоритетними мають бути міжнародні зв’язки з країнами-сусідами і цим самим сприяти позитивному вирішенню проблем виходу з кризи. 


\section{Список використаних джерел}

1. Наукова та інноваційна діяльність в Україні. Стат. сб. - К.: Держкомстат. 2006. -312 c.

2. Иллященко C. М. Управление инновационным развитием: проблемы, концепции, методы: / С. М. Илляшенко. - Сумы: ВТД «Университет кн.», 2003. $278 \mathrm{c}$.

3. Євробюлетень. Інформаційне видання Представництва Європейської Комісії в Україні, Молдові та Бєларусі. №2, лютий, 2006. - 256с.

4. Євробюлетень. Інформаційне видання Представництва Європейської Комісії в Україні, Молдові та Бєларусі. №8, серпень, 2005. - 198с.

5. Свробюлетень. Інформаційне видання Представництва Європейської Комісії в Україні, Молдові та Бєларусі. №6, червень, 2006. - 232с.

\section{МЕЖДУНАРОДНОЕ СОТРУДНИЧЕСТВО КАК ЗАЛОГ ИННОВАЦИОННОГО ПРОЦЕССА В НАЦИОНАЛЬНОЙ ЭКОНОМИКЕ \\ Рыбак С. А., Лисецкая Н. Н.}

\section{Аннотация}

В роботе показана необходимость всемирной кооперации в направлении дальнейшей интенсификации инновационных процессов и в частности оценена современная позиция Украины в системе Европейской программы инновационного обмена между странами. Проанализированы современные программы Европейской кооперации в инновационном сотрудничестве стран. Определены основные области инновационного потенциала Украины.

Ключевые слова: инновационное развитие, международное сотрудничество, финансовые механизмы.

\section{INTERNATIONAL COOPERATION AS THE DRIVING FORCE OF INNOVATION DEVELOPMENT OF UKRAINIAN ECONOMY Rybak S., Lisetska N.}

\section{Resume}

The article proves the demand of global integration in development of innovation process. In the article it has been assessed modern position of Ukraine in European program of innovation exchange between countries. Modern European Corporation in 
program of innovation cooperation has been analyzing. The basic areas of Ukrainian innovation potential are defined.

Keywords: innovation development, international cooperation, finance mechanisms. 